\title{
A POLITIZAÇÃO DO REGRESSO AO IMPÉRIO DOS VETERANOS DA GUERRA DO PARAGUAI ${ }^{1}$
}

\author{
Rodrigo Goyena Soares ${ }^{2}$
}

\begin{abstract}
Vem até nós, famoso Ulisses, glória maior dos Aqueus! Detenha a nau, para que nos possas ouvir! Pois nunca por nós passou nenhum homem na sua escura nau que não ouvisse primeiro o doce canto de nossas bocas; depois de se deleitar, prossiga caminho, já mais sabedor.

Pois nós sabemos todas as coisas que na ampla Troia

Argivos e Troianos sofreram pela vontade dos deuses; e sabemos todas as coisas que aconteceram na terra fértil!
\end{abstract}

Homero, Odisseia, Canto XII.

Conta o duodécimo canto da Odisseia que, após retornaram à ilha de Circe, os remadores e demais marinheiros da nau de Ulisses foram objeto de sedução das sereias. Os seduziam, para que a nau se desnorteasse, e o destino de Ulisses e de seus marinheiros se perdesse no passado. Deixariam então de ser senhores de seus destinos. O recurso de Ulisses foi colocar cera nos ouvidos de seus soldados, aconselhando-os a remar até a exaustão dos músculos. Ele, no entanto, amarrou-se ao mastro do navio. Ouviria o canto, mas não poderia se aproximar das sereias.

Qual não foi o assombro do veterano da Guerra do Paraguai, naquele primeiro semestre de 1870, ao perceber que, após anos de combate e apesar da vitória, não era sua reinserção na sociedade o que estava em jogo, mas o desenrolar da história dos gabinetes. Ou melhor, não era a ressocialização desmilitarizada do combatente o que estava em discussão, mas dirimir a qual partido os militares pertenceriam. A legião de liberais reformistas não foi a única que buscou nas Forças Armadas o suporte político que lhe faltava. Liberais radicais procederam no mesmo sentido. E os conservadores também, apesar do contrassenso: afinal, não foram eles os entusiastas de um rápido regresso dos veteranos ${ }^{3}$.

A querela do retorno atravessou o ano de 1870. As comemorações e festividades públicas foram mais motivo de enaltecimento ou crítica ao governo do que uma passagem das Forças Armadas ao primeiro plano. O governo conservador de Itaboraí desconfiava da politização dos militares. O mais adequado, julgava, era ganhar as

\footnotetext{
${ }^{1}$ Agradeço os comentários e as sugestões de Rafael Marquese e de Ricardo Salles. A publicação deste artigo, que ocorreu na passagem do doutorado para o pós-doutorado, contou com apoio da Fundação de Amparo à Pesquisa do Estado do Rio de Janeiro e, ainda, da Fundação de Amparo à Pesquisa do Estado de São Paulo, instituições às quais sou muito grato.

${ }^{2}$ Doutor em História pela Universidade Federal do Estado do Rio de Janeiro. Desde 2017, atua na Universidade de São Paulo no âmbito do pós-doutorado em História. E-mail: $<$ rodrigo.goyenasoares@gmail.com>.

${ }^{3}$ GOYENA SOARES, Rodrigo (org.). Conde d'Eu: Diário do comandante em chefe das tropas brasileiras em operação na República do Paraguai. Rio de Janeiro: Paz \& Terra, 2017.
} 
Forças Armadas mediante a concessão das promessas de campanha ${ }^{4}$, e isso em que pese a política de contenção de gastos promovida após a guerra. Com as vantagens, os conservadores assegurariam que as Forças Armadas não ultrapassem as fronteiras de seu lugar constitucional: servir ao Estado, e ao governo também.

Sujeitar as Forças Armadas era de maior importância, tendo em vista, em primeiro lugar, a ação dos reformistas. É certo que os conservadores não enxergavam grande risco nos oficiais liberais do Exército, mas não por isso deixariam que o reformismo, sobretudo por iniciativa dos civis, se alastrasse na caserna. Caxias e os demais oficiais conservadores de alta patente fariam o trabalho hierárquico nesse sentido. Quantos aos radicais, estimava o gabinete que havia mais palavras inflamadas do que possibilidades de ação concreta. Eram poucos, e não tinham grandes capacidades de incidir nas eleições. O que não quer dizer, por outro lado, que os radicais tenham poupado esforços para republicanizar as tropas.

Vejamos, portanto, como se deu o embate pelo apoio das Forças Armadas e em que medida o efeito desse embate foi, quiçá menos paradoxalmente do que possa parecer, realçar a autonomia da caserna, quase como se o oficialato superior tivesse colocado a cera de Ulisses nos ouvidos de praças e de oficiais inferiores.

\section{Os partidos à procura das Forças Armadas}

Os reformistas desconfiaram significativamente mais da ação dos radicais do que os conservadores. Em que pese as tentativas para formar com eles um bloco oposicionista único contra Itaboraí, os radicais não cederam. O garboso retorno ao Império do Conde d'Eu, visto como um liberal na Corte, não foi cimento denso o suficiente para unir os radicais ao grupo reformista. Pelo contrário, os radicais enxergaram no príncipe consorte o principal tolhimento ao que, em abril de 1870, já era mote de ação política: instituir a república no Brasil.

Inclusive após o politizado retorno dos Voluntários da Pátria, alguns reformistas, como Joaquim Nabuco, ainda guardavam esperança na união com os radicais. Dizia Nabuco, assim como seu pai, que a divisão entre republicanos e liberais, ou radicais e reformistas, era um tanto artificial, prejudicial à causa democrática e, sobretudo, do interesse dos conservadores. Monarquias, escreveu em A Reforma no dia 19 de junho de 1873, poderiam ser várias, e repúblicas, também: venezianas, cesaristas e militaristas ${ }^{5}$. Outros, como Francisco José Furtado, não acreditaram um segundo na ligação com os radicais, $e$ isso, aliás, antes do retorno dos veteranos. Não obstante a formação do Centro Liberal, em 1868, Furtado não vislumbrava força no reformismo. Previa o pior na silenciosa intimidade de seu diário pessoal: um golpe de Estado.

A revolução triunfante será a divisão do Império, e a anarquia será a consequência. Teremos grandes desgraças, mais cedo ou mais tarde, e a monarquia sucumbirá. [...]. As ideias republicanas, que eram apenas partilhadas por mui

\footnotetext{
${ }^{4}$ GOYENA SOARES, Rodrigo. "Promessas da campanha do Paraguai e recompensas do regresso". In: RODRIGUES, Fernando da Silva, FERRAZ, Francisco e PINTO, Surama Conde Sá (orgs.). História militar: novos caminhos e novas abordagens. Jundiaí: Paco Editorial, 2015.

${ }^{5}$ SALLES, Ricardo. Joaquim Nabuco, um pensador do império. Rio de Janeiro: Topbooks, 2002, p. 8687.
} 
poucos homens, alguns moços entusiastas, que não formaram partido, vão ganhando terreno, assim como o ódio ao Imperador. ${ }^{6}$

Entre crédulos e incrédulos, cabia ao Conde d'Eu, pelo menos assim o fez acreditar Joaquim Manuel de Macedo, o papel de docilizar os radicais. E nisso fracassou inteiramente. De alguma forma, o próprio Conde sabia, ainda quando em campanha, que a hercúlea tarefa estava mais para a mitologia do que para a realidade política. Em abril de 1869 - portanto, poucos dias após ter deixado o Império em direção ao Paraguai -, o Conde d'Eu enviou carta à Princesa Isabel, na qual comentava, não sem alguma dose de exagero, a respeito de uma certa efervescência política no Exército que se devia, principalmente, a Quintino Bocaíuva ${ }^{7}$. Era aquela uma efervescência radical, não restava dúvida, promovida por quem viria a ser um dos principais redatores do Manifesto Republicano de dezembro de 1870.

Ao chegar à Corte, em abril de 1870, e passada a exaltada comemoração por seu regresso, o Conde compreendeu que os radicais haviam tomado rumo próprio. Bastava ler as inflamadas páginas da Opinião Liberal, principal órgão dos radicais. O jornal havia sido fundado em 21 de abril de 1866 por Francisco Rangel Pestana, Henrique Limpo de Abreu e José Luiz Monteiro de Souza. E seu principal objetivo era combater os reformistas, entre eles, o Conde d'Eu.

Com o retorno dos veteranos ao Império, a distinção entre radicais e reformistas tornou-se menos artificial. Assim quiserem os radicais. Não era o mesmo ser emancipacionista ou abolicionista, nem tampouco advogado da descentralização ou da federação. E muito menos, monarquista ou republicano. Entres os radicais, não se discutia a reponsabilidade dos ministros, reclamava-se a extinção do Poder Moderador. No lugar de preconizar a reforma da Guarda Nacional, aconselhava-se sua erradicação ${ }^{8}$.

\footnotetext{
${ }^{6}$ Instituto Histórico Geográfico Brasileiro - DL 466.30. Diário pessoal de Francisco José Furtado.

${ }^{7}$ Arquivo Histórico Museu Imperial - XLII-3 (17-19). Conde d'Eu para Princesa Isabel, Legação do Brasil em Montevidéu, 6/04/1869.

8 CARVALHO, José Murilo de. "Radicalismo e republicanismo". In: CARVALHO, José Murilo de e NEVES, Lúcia Bastos Pereira das (orgs.). Repensando o Brasil do Oitocentos. Cidadania, política e liberdade. Rio de Janeiro: Civilização Brasileira, 2009, p. 33.
} 


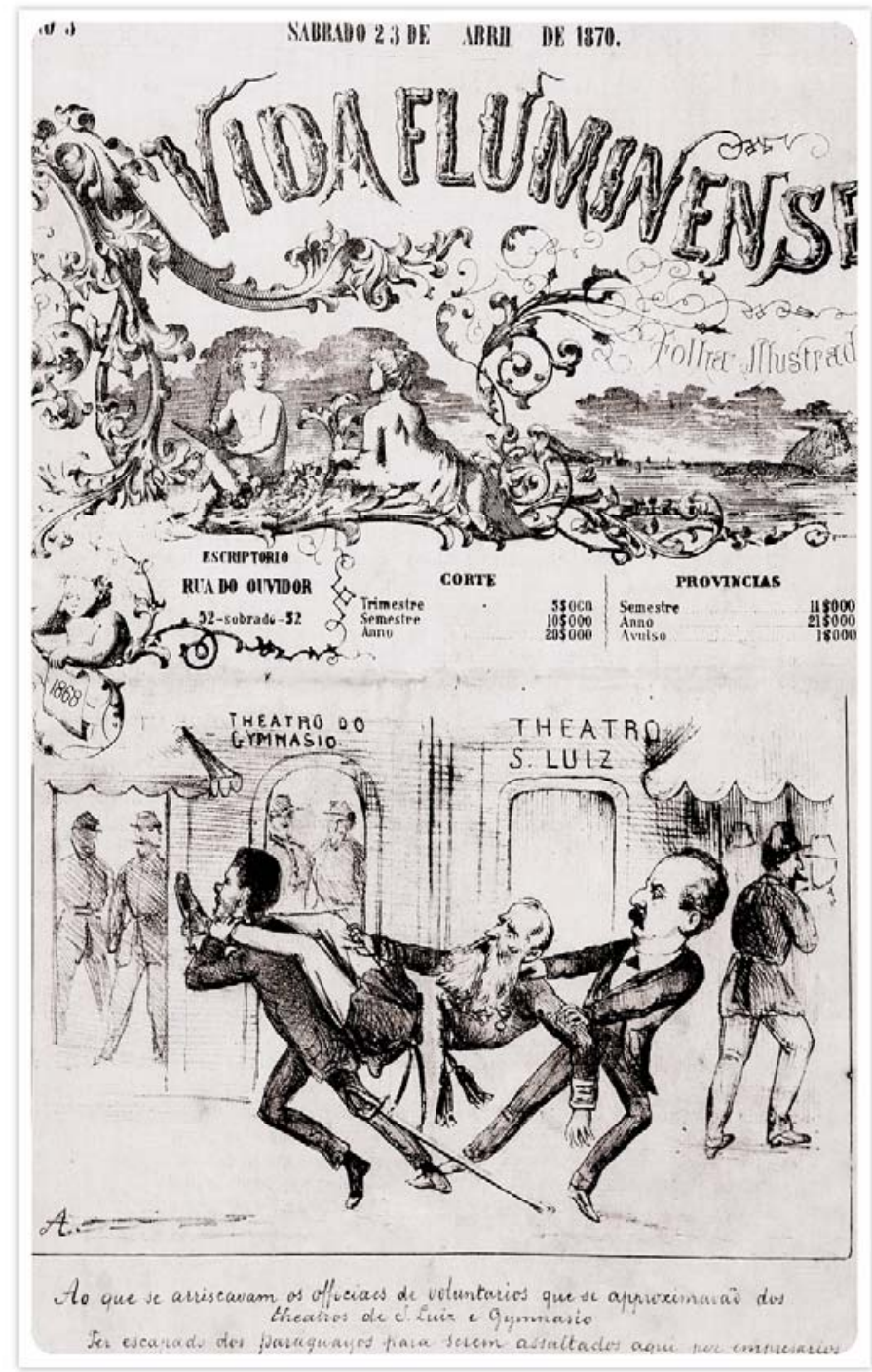

Figura 1: Ângelo Agostini sobre o retorno dos veteranos ao Império. Fonte: A Vida Fluminense, 23/04/1870. Legenda: "Ao que se arriscam os oficiais de Voluntários que se aproximaram dos teatros de São Luiz e Ginásio. Ter escapado dos paraguaios para serem assaltados aqui por empresários!". O Teatro Ginásio era tradicional reduto dos conservadores, ao passo que o Teatro São Luiz, dos liberais.

Certo é que, antes do regresso dos combatentes, as agendas reformista e radical não se superpunham completamente. Mas, com a volta, as diferenças deixaram de ser matizes. De alguma forma, os radicais perceberam que os reformistas usariam tanto o retorno dos Voluntários da Pátria quanto a posição política do Conde d'Eu para formar frente única de oposição a Itaboraí. Julgaram que, no decurso do processo, terminaram perdendo suas vagas em eventual queda do gabinete conservador. Não por acaso, aproveitaram o regresso dos veteranos do Paraguai para fazer valer as diferenças entre os programas políticos e para maldizer o príncipe consorte. Haviamse enganado Afonso Celso de Assis Figueiredo, Anfrísio Fialho, Joaquim Manuel de Macedo, Silveira Martins e Francisco Otaviano: A Reforma não era a Opinião Liberal. 
Dois dias antes da chegada da primeira leva de combatentes ao Brasil, e entrando na querela do regresso, os radicais estamparam na primeira página da Opinião Liberal a existência de dois partidos no Brasil. Não falavam em partidos como instâncias meramente político-eleitorais, mas como organizações capazes de tornar real o que existe em potencial ${ }^{9}$ - partidos como ferramenta de classe, ora para consolidar uma situação socioeconômica dada, ora para derrubar essa situação em proveito de uma nova. Sentiam-se, de alguma forma, autorizados a falar em nome de uma classe que chamavam de oprimida.

O primeiro seria o partido imperialista, aquele que dominava, que estava satisfeito com a escravidão, que conservava preconceitos coloniais e privilégios dos senhores e dos patrões. Que julgava possível um Brasil sem indústria. Que se vestia de fraque e de botina com bico fino. E que se alimentava de produtos importados. Reformistas e conservadores seriam tão simplesmente a voz eleitoral desse partido. O segundo seria o dos oprimidos. Voz da esmagadora maioria, que vivia sem ou de pequenos salários, que morava onde podia, que trabalhava, manualmente, onde surgisse emprego, que vestia camisa de chita e calça de brim, algumas vezes, sem sapatos. Desorganizados, propunha a Opinião Liberal, teriam lugar na política unicamente mediante a ação dos radicais, que enxergavam mudança somente na queda da monarquia ${ }^{10}$.

$\mathrm{O}$ caso é que os radicais viam nesses oprimidos, também, os veteranos da Guerra do Paraguai. Oprimidos pela guerra, voltariam à casa oprimidos por uma sociedade desigual. O momento não poderia ser mais adequado para ressaltar a visão política dos radicais, diferenciando-a cada vez mais daquela dos reformistas. Mas não só. A oportunidade era boa para ganhar o apoio das Forças Armadas, que, pensava-se, poderiam ser o espelho armado das alas radicais, já marcadamente republicanas. Ou, no pior dos casos, a hora era oportuna para não deixar que as Forças Armadas assumissem coloração reformista. Em longo, porém revelador, editorial do dia 28 de fevereiro de 1870, arguia a Opinião Liberal:

Depois de cinco anos de sofrimento acerbos, volvem ao seio da pátria as preciosas relíquias das legiões brasileiras. Volvem com o peito transpassado pelo aguilhão da eterna saudade dos bravos companheiros, cujos ossadas alvejam os esteiros paraguaios; volvem com o coração cheio de presságios funestos, que lhes suscita a fisionomia angustiada desta nova Roma. Esperam eles por ventura repousar sobre os louros conquistados ao chefe bárbaro? Retalhado pela intriga latente dos eunucos do poder, este baixo Império não lhes pode senão oferecer desolação e penúria, que é a partilha do povo no governo dos césares. E essa intriga latente dos eunucos prende-se à conspiração que lá se trama nos campos da caçada militar de Caraguataí. Aclamado imperator [grifado no original], depois de Peribebuí, pela turba dos cortesãos da

\footnotetext{
${ }^{9}$ GRAMSCI, Antonio. Os intelectuais e a organização da cultura. Rio de Janeiro: Civilização Brasileira, 1982; e PIOTTE, Jean-Marie. La pensée politique de Gramsci. Québec: Lux Éditeur, 2010.

${ }^{10}$ Opinião Liberal, 21/02/1870.
} 
campanha, o novo César, que tem pressa de construir as bases de seu futuro reinado, conta apoiar-se nas briosas legiões brasileiras, pretendendo rebaixar estes bravos ao papel de instrumentos de seu futuro domínio. O suspeitoso Tibério, porém, corre ao encontro das falanges vitoriosas, prescreve-lhes um itinerário longo e cerimonioso, obriga-as a forçadas estações que lhes reprimem o ardor marcial, como o cansaço do corpo, que abate a altivez do espírito. [...]. Os infectos acampamentos do curtume, as imundas planícies de São Cristóvão serão para ele [o Conde d'Eu] os campos de Hebdomem, onde os eunucos da Corte decadente irão semear a contraconspiração. Mas enquanto os dois césares e seu eunucos se disputam amigavelmente [grifado no original] a influência militar; enquanto as ambições divinas [grifado no original] ousam converter o heroísmo em instrumento de seus vis interesses; enquanto, finalmente, os cortesãos do senhor Dom Pedro e os do senhor Gastão disputam a posse deste país através das sombras do reposteiro, supondo envolver os filhos queridos da pátria neste oceano de tétricas intrigas, o que se tem passado no coração destes bravos ao pisarem o solo devastado de sua pátria querida? Vítimas de injúrias e de sofrimentos; preteridos nos seus mais sagrados $e$ incontestáveis direitos; vilipendiados pelas mais falazes promessas; sem soldo e sem recompensa, esses corações patrióticos divisam na fisionomia entristecida do povo brasileiro o reflexo da opressão que lhes vai na alma. Filhos do povo, deparam com os traços da mais funda pobreza na face angustiada do povo: denodados libertadores da pátria no estrangeiro, contemplam-na manietada e agonizante no interior! [...]. Não vos espera o repouso, mas as atribulações do espírito! As primeiras efusões do entusiasmo e do delírio, que inspira o aspecto venerando das falanges vitoriosas, cessarão brevemente, para vos deixar cair na triste contemplação dos mais fundos desgostos! Em face do declínio das liberdades pátrias, envolvidos pelas privações que virão encontrar no lar doméstico, esses valentes filhos da democracia saberão reagir contra as ambições e intrigas do palácio e salvar a causa do futuro. Os zangóes coroados serão severamente castigados pelo soberano desprezo dos dignos filhos do Brasil, e os eunucos do rei e do pretendente serão esmagados pela planta vitoriosa dos bravos filhos do povo. Voluntários da Pátria! A vossa missão de soldado cessou, para recomeçar a tarefa de cidadão! Apóstolos da 
liberdade! Desfraldai o estandarte da democracia, e combatamos todos pela felicidade e grandeza da pátria! ${ }^{11}$

Certamente havia algo de exagero na linguagem barroca da Opinião Liberal. Ainda no gabinete de Itaboraí, que durou até setembro de 1870, as promessas foram motivo de preocupação. Mas também havia algo de premonição: afinal, a República se fez. O caso é que os radicais se queriam autônomos em relação à disputa partidária pelos veteranos. Alheios, portanto, às "tétricas intrigas dos cortesãos" - que não eram senão os reformistas e os conservadores -, mas não à sociedade. Diziam-se a voz dos que não tinham voz em São Cristóvão, incluindo, não por acaso, os militares.

O editorial deixava claro que os veteranos, especialmente os Voluntários da Pátria, eram aqueles em nome de quem os radicais falavam: "o povo brasileiro, os filhos do povo, os filhos da democracia". As expressões não eram recurso estilístico. Eram recurso político, isto é, maneira de não cindir o bloco dos oprimidos. Ou antes, de dar suporte a esses que chamavam de oprimidos. De alguma forma, o editorial equiparava a condição de Voluntários da Pátria - ou simplesmente a das Forças Armadas - com aquela do "povo brasileiro": eram "os de fisionomia entristecida, as vítimas de injúrias e de sofrimentos, os preteridos em seus mais sagrados e incontestáveis direitos".

Forçar o traço das semelhanças entre os oprimidos e os veteranos era maneira de evitar que as Forças Armadas fossem cooptadas pelos reformistas. Era fundamental então deixar indefinições sobre a identidade desses oprimidos. De modo contrário, seria mais fácil não se sentir parte. Era melhor o eles, "cortesãos", contra nós, o "povo". Os radicais alertavam a caserna sobre a "caçada pelos militares" que estava em marcha por obra do principal reformista: o "aclamado imperator, o novo césar, o Tibério"12.

Falavam do Conde d'Eu. Esse que "abateria a altivez de espírito" do veterano, sua força de ação autônoma. Esse que regeria a "contraconspiração", ou a contrarrevolução, à revolução que queriam os radicais. A revolução era a república, trocando em miúdos. Terminaram o editorial conclamando pela ação conjunta: os radicais $e$ as Forças Armadas "saberiam reagir contra as ambiçóes e intrigas do palácio, e salvar a causa do futuro". Cabia agora "desfraldar o estandarte da democracia e combater, todos, pela felicidade e grandeza da pátria", e, poderiam ter continuado, por uma república civil, embora feita com os militares.

Naquela altura, parecia claro que havia, pelos menos no entender dos radicais, três forças políticas no Império do Brasil: os conservadores, os liberais (em referência aos reformistas) e os republicanos (que eram os radicais). Seguiram-se semanas de editoriais da Opinião Liberal que fustigavam os liberais e os conservadores. Dois alvos constantes eram o Duque de Caxias e o Conde d'Eu. Na luta entre "duquistas" e "condistas", dizia-se na Opinião Liberal, o melhor era ser contra os dois, porque, ao fim e ao cabo, eram os mesmos ${ }^{13}$.

\footnotetext{
${ }^{11}$ Opinião Liberal, 28/02/1870.

12 Tibério Nero César (42 a.C.-37 d.C.) foi Imperador romano de 18 de setembro de 14 até sua morte, em 37. Foi durante seu reinado que, na província romana da Palestina, Jesus de Nazaré foi crucificado.

${ }^{13}$ Opinião Liberal, 30/04/1870.
} 
Malgrado o verbo inflamado, os republicanos não pareciam estar ganhando a batalha do retorno. Longe disso. Transitou nas mesas de deputados, senadores e conselheiros de Estado o número de fevereiro de 1870 da Revue des Deux Mondes, no qual se trazia a público o que já era sabido entre muitos liberais: o Conde d'Eu era emancipacionista ${ }^{14}$. Os radicais mostraram-se surpresos com a notícia, temendo perder espaço na caserna. Sabiam da vertente abolicionista de algumas lideranças do Exército. $\mathrm{O}$ emancipacionismo do Conde, nesse sentido, seria contrapeso à influência dos radicais nas Forças Armadas, especialmente, no Exército. De forma desajeitada, provavelmente por não encontrar melhor argumento, tentaram minimizar $\mathrm{o}$ emancipacionismo do Conde d'Eu, sustentando que nada fazia para acelerar a marcha da alforria no Brasil.

Maio, junho e julho foram meses difíceis para os radicais. Para eles, o inverno parecia ter-se adiantado. Ao retornar do Paraguai em 29 de abril de 1870, o Conde d'Eu foi ovacionado por uma multidão que encheu a rua Direita até o Paço Imperial. Ao pisar em terra firme, o Conde encontrou-se com o Imperador, com a Imperatriz e, naturalmente, com a Princesa Isabel. Para os radicais, que com olhar crítico foram ao Paço, o Conde não estava matando as saudades da esposa e dos sogros. Estava fazendo política. O pior, no entanto, estava por vir.

No dia $1^{\circ}$ de maio, a população da Corte foi em grande número assistir ao tedéum que se cantou no Outeiro da Glória. Entusiasmada, a multidão rompeu pelas alas da guarda imperial e cercou o Outeiro por todos os lados. Regia a orquestra ninguém outro que o mulato Henrique Alves de Mesquita. Quando começaram a ressoar os violinos, a multidão avançou sobre as áreas de plantio, na Praça da Glória, e deu vivas ao Conde d'Eu. À noite, o clima festivo não se acalmou. Iluminou-se o bairro da Glória à luz elétrica, e bandas carnavalescas, entre elas a Sociedade dos Tenentes do Diabo, percorram as ruas, algumas entoando o hino Conde d'Eu, da lavra de Artur Napoleão, compositor e professor de Chiquinha Gonzaga, e com letra de Franklin Dória, deputado liberal e futuro ministro da Guerra ${ }^{15}$. Nas semanas seguintes - maio adentro, portanto -, a agitação não cessou, e Charles Greenough, presidente da Companhia Ferro-Carril do Jardim Botânico, desabafou junto à diretoria nova-iorquina da empresa: "temos tido semanas exaustivas. Para nós e para os animais. Felizmente, o serviço vai voltando à normalidade. Trafegamos, quase que ininterruptamente, com todos os nossos 32 carros. Oxalá tivéssemos tido 50 ou 60 para servir ao público naqueles dias"16.

Foram dias demais de comemoração, pensaram os radicais. $\mathrm{O}$ reconforto era não acreditar na coesão daquela massa. Uma multidão incontável, mas de interesses específicos e pequenos, pulverizados. Haveria quem foi ao encontro do Conde para ver Mesquita tocar, na verdade. Também aquele que foi à Glória para voltar a ver o rosto da amante, sem a escuridão da meia-noite. E outro que somente queria saber da farra. Impossível dizer se a massa que alegrou a Corte naqueles dias fazia-o por admiração ao Conde, por amor à monarquia ou, simplesmente, por êxtase pelo fim da guerra.

\footnotetext{
${ }^{14}$ Opinião Liberal, 23/04/1870.

${ }^{15}$ Ver: DUNLOP, Charles L. Apontamentos para a história dos Bondes no Rio de Janeiro. Vol. II. Rio de Janeiro: Editora Laemmert, 1953, p. 33-37.

${ }^{16}$ DUNLOP, Charles L. Apontamentos para a história dos Bondes...
} 
Ocorre que tão logo se acalmou a cidade, correu a notícia de uma possível nomeação do príncipe consorte para o Conselho de Estado. São Cristóvão estava empenhado na questão. E contra isso, poucas eram as chances dos radicais: não seriam os liberais que se oporiam à decisão que, em última instância, cabia ao Imperador - $e$ tampouco os conservadores, apesar das desconfianças em relação ao Conde d'Eu. Neste caso, tentativas para abafar o Conde poderiam pôr em risco o próprio gabinete.

Jactando-se da previsível vitória liberal, Zacarias de Goés e Vasconcellos encerrou a sessão de 7 de julho de 1870, no Senado, com enorme provocação aos conservadores. Não escapou a nenhum dos senadores, naquela manhã, que Zacarias se vingava de Caxias. "Qual foi o general a quem tamanha glória deve o Brasil?", ponderou com discreto mas inevitável sorriso entre os lábios. Abriu então o número de fevereiro de 1870 da Revue des Deux Mondes e comentou, limpando um pigarro imaginário, que, segundo os redatores, foi o Conde d'Eu quem vencera a Guerra do Paraguai. E ainda, que Caxias tinha deixado o conflito sem autorização do governo quase uma deserção, queria dizer - $e$ que, devido a sua popularidade nas Forças Armadas, o príncipe consorte era um bom nome para o Conselho de Estado ${ }^{17}$.

$\mathrm{O}$ que Caxias poderia dizer, ele que estava presente naquela sessão do Senado? Pouco. Sucinto, o Duque de Caxias arguiu que se retirou do combate, porque estava doente. E que tinha autorização do governo. Recordou os êxitos nas batalhas da Dezembrada e não disse palavra sobre a popularidade do príncipe, nem sobre a indicação dele para o Conselho de Estado. Zacarias voltou a provocar os conservadores, recordando as barreiras impostas ao príncipe para ir ao Paraguai. Caxias guardou silêncio, e a sessão terminou-se sob aplausos dos liberais.

17 Anais do Senado Federal, 7 de julho de 1870. Brasília: Senado Federal. Disponível em: $<$ http://www.senado.gov.br/publicacoes/anais > . Acesso em: 7 de janeiro de 2016. 


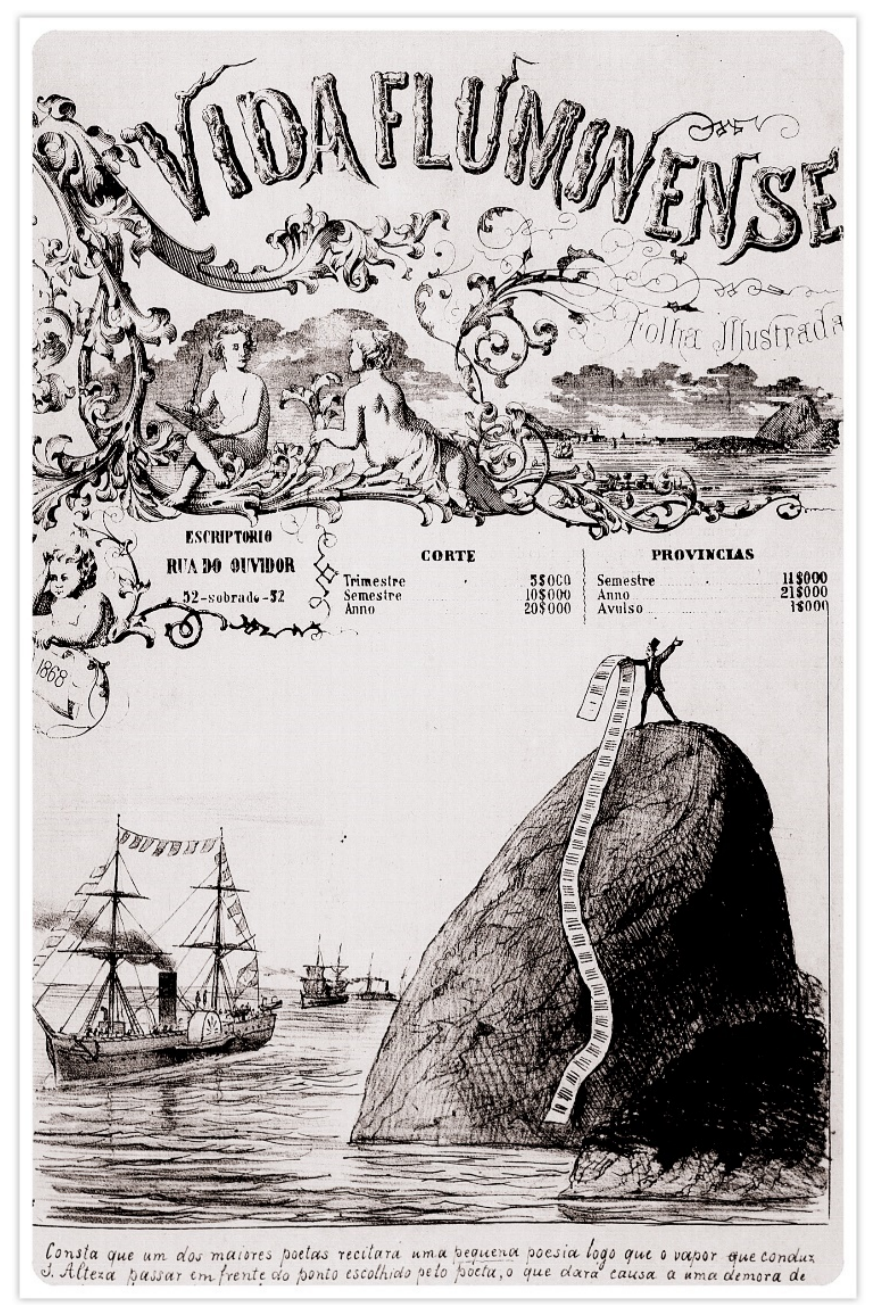

Figura 2: Ângelo Agostini sobre o retorno do Conde d'Eu ao Império. Fonte: A Vida Fluminense, 30/04/1870. Legendas: "Consta que um dos maiores poetas recitará uma pequena poesia logo que o vapor que conduz Sua Alteza passar em frente ao ponto escolhido pelo poeta, o que dará causa a uma demora de mais de doze hora pelo menos!"

Um dia depois, em 8 de julho de 1870, o Conde d'Eu foi nomeado conselheiro de Estado. Não era uma sinecura. O Conselho de Estado era ouvido pelo Imperador, no que concernia à política externa, em casos de declaração de guerra, de ajustes de paz, de negociações com nações estrangeiras; $e$, quanto à política interna, quando o Poder Moderador era exercido ou quando se formulavam e se aplicavam abrangentes medidas de administração pública. Havia ainda sessões especiais para assuntos de Justiça e de Negócios Estrangeiros, de Império, de Fazenda e de Marinha e Guerra.

Os radicais tentaram incendiar o acontecimento, mas não tiveram grande repercussão. Disseram que o Conselho de Estado era chave para influir sobre os rumos do Império, que o Conde terminaria dominando-o e, que, portanto, o Brasil seria governado por um marechal: 
O senhor Orléans foi fiel aos caminhos de César. Apoderouse do Exército [...]. Quem lhe oporá? Os conservadores? Estes estão bem com o que cedem e estarão melhor com o que vier. Os liberais? Aclamaram-no marechal do Exército e conselheiro de Estado e, ainda mais, chefe do partido! E, quem o pensara!, há mesmo republicanos que esperam fazer do bisneto de Egalité o presidente da República brasileira, posição que, dizem eles, Sua Alteza aspira ardentemente! Pois bem: que passe mais esta, unânime aclamação dos povos. Mas que aqueles que hoje bradam contra o governo paisano e pessoal de Dom Pedro II jamais se lembrem de debelar o governo militar e pessoalíssimo do senhor Gastão que eles mesmos criaram! ${ }^{18}$

As considerações eram exageradas. Liberais e conservadores sabiam-no. E, quiçá, radicais também. A estratégia dos conservadores foi bem outra. Com o regresso do Conde d'Eu à Corte, evitaram criticá-lo. Pelo contrário, adotaram posição de enaltecimento à ação militar do príncipe, sem que isso significasse demérito a outros generais, especialmente, os conservadores. $\mathrm{E}$, no ensejo, não pouparam elogios às Forças Armadas ${ }^{19}$.

O Dezesseis de Julho, órgão conservador, cujo nome fazia referência à data de constituição do gabinete de Itaboraí, foi implacável em suas tentativas de congelar a ação dos liberais e dos radicais. Embora os conservadores não vislumbrassem grande perigo na ação dos oficiais liberais do Exército, que seriam tolhidos por seus homólogos conservadores, não deixariam que liberais e radicais civis contagiassem, sobretudo, os batalhões de Voluntários da Pátria. Afora a concessão das promessas de campanha, o que era fundamental para evitar tanto a politização dos Voluntários que permanecessem na caserna quanto a dos que não, era necessário entrar na batalha das influências. Ou desmistificar os resultados eventuais do que os radicais chamavam de revolução:

Revolucionar não é ganhar, não é servir: é desmoralizar-se, é perder-se. A revolução é o pior de todos os jogos: os povos revolucionários são os mais infelizes e hediondos de todos os jogadores; na revolução, ninguém ganha [...]. Ela é a origem de todos os excessos, e só produz anarquia, esse despotismo de mil cabeças, pior que o López. [...]. Todas as revoluções que não são de ideias, todas as revoluções que não saem da urna e que não se fazem no Parlamento, são criminosos, são infames. [...]. ${ }^{20}$

\footnotetext{
${ }^{18}$ Opinião Liberal, 9/07/1870.

${ }^{19}$ Dezesseis de Julho, 23/02/1870.

${ }^{20}$ Dezesseis de Julho, 3/03/1870.
} 
Trazia o Dezesseis de Julho dois exemplos a serem seguidos, e outros dois contraexemplos. Os modelos eram a Alemanha e a Itália. Os conservadores bateram palmas para Bismarck e para Cavour, enxergando neles as forças contrarrevolucionárias que não somente fizeram, respectivamente, a unificação da Alemanha e da Itália, mas que também asseguraram a paz social em seus Estados. Haviam feito revoluções passivas: antes, portanto, que militares ou republicanos fizessem revoluções ativas. O que havia de ser evitado era o caso da França e da Espanha. Napoleão III perdia terreno para os republicanos, fossem civis ou militares. E uma guerra contra Bismarck, caso ocorresse, terminaria por desmantelar o Segundo Império francês. Nisso, os conservadores não se equivocaram. Na Espanha, a situação era ainda mais desesperadora. Em meados da década de 1860, progressistas e democratas haviam-se unido contra Isabel II. Em 1865, e fazendo coro com as vozes descontentes, ocorreram sublevação nos quartéis militares, em muito devido às perdas na Guerra Hispano-Sul-americana (1865-1866), que opôs a Bolívia, o Chile, o Equador e o Peru à Espanha. Em 1868, proclamou-se a Revolución Gloriosa, e ruiu o reinado de Isabel II. 


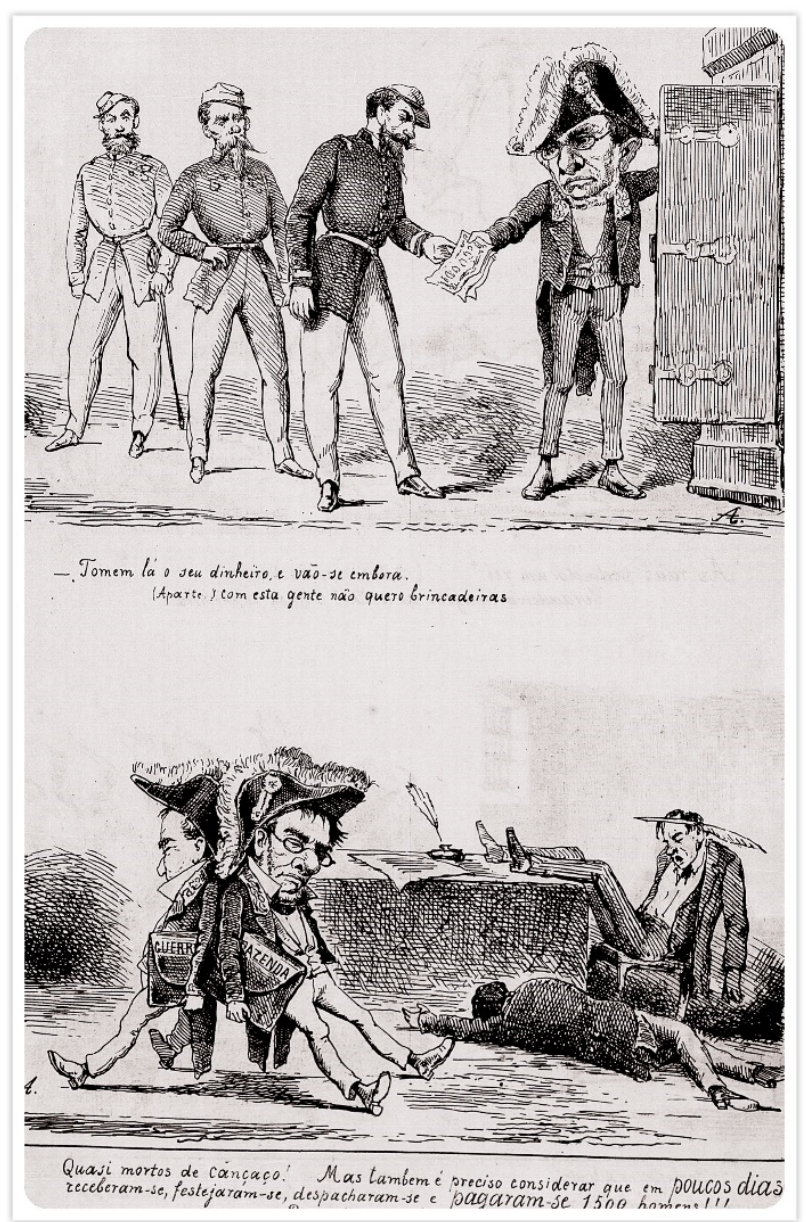

Figura 3: Ângelo Agostini sobre o retorno dos veteranos ao Império (II). Fonte: A Vida Fluminense, 12/03/1870. Legendas: (acima) "Tomem lá o seu dinheiro, e vão-se embora. (Aparte) Com esta gente não quero brincadeiras"; (embaixo) "Quase mortos de cansaço! Mas também é preciso considerar que em poucos dias receberam-se, festejaram-se, despacharam-se e pagaram-se 1.500 homens!!!”.

Não que a república no Brasil fosse uma real possibilidade, pelo menos no entender dos conservadores, mas era primordial não deixar que a ideia revolucionária alcançasse os Voluntários. E, por extensão, os brasileiros como um todo. "Em vez de defender a pátria", comentou o Visconde de Itaboraí ao conselheiro José Carlos de Almeida Arêas, referindo-se aos republicanos franceses quando da Guerra FrancoPrussiana (1870-1871), "cantam a marselhesa; dão vivas à República e derrubam estátuas" ${ }^{21}$. Era o cenário a se evitar. Assim que retornaram os veteranos, o Dezesseis de Julho entabulou uma cruzada para desfazer a ação dos liberais e dos radicais. Sabiam dos editoriais, panfletos e folhetos de cunho reformista ou republicano que foram distribuídos aos Voluntários da Pátria ${ }^{22}$. Os rebateram todos: "o Exército

\footnotetext{
${ }^{21}$ Instituto Histórico Geográfico Brasileiro - Lata 157, pasta 8. Visconde de Itaboraí para José Carlos de Almeida Arêas, Rio de Janeiro, 6/10/1870.

${ }^{22}$ Dezesseis de Julho, 3/03/1870.
} 
brasileiro não é o inimigo do povo, nem do trono, nem da justiça", afirmava o Dezesseis de Julho, "a sua bravura é tão grande quanto sua dedicação pelos altos poderes do Estado"23.

Não era a revolução o que os veteranos deveriam buscar, mas a "moral" $e$ o "senso comum": "os bravos Voluntários da Pátria sabem que a disciplina, no Exército, e o trabalho, na sociedade, são a salvação do Exército e a salvação da sociedade" ${ }^{24}$. A liberdade, para os conservadores, alcançar-se-ia pela instrução, pela ordem e pela moralidade: "a civilização se ganha pela paz, pelo trabalho e pela paciência" ${ }^{25}$. Em outras palavras, não era o motim ou a sublevação o lugar do veterano, mas a disciplina militar ou a retidão civil. O regresso era para o trabalho $e$ para a família. Cada um em seu espaço na cadeia administrativa ou produtiva, e cada qual em seus lugares de reprodução social. A ascensão social viria, poderiam ter concluído os conservadores no Dezesseis de Julho, bastava ter paciência: era essa a "moral", e era esse o "senso comum".

$\mathrm{O}$ embate entre conservadores, liberais e radicais, como era de esperar, não se restringiu à Corte. As tensões políticas pelo regresso dos veteranos reproduziram-se nas províncias ${ }^{26}$. Após demorado desfile pela rua do Taboão, na cidade de Salvador, os veteranos detiveram-se em frente à Igreja de Nossa Senhora do Rosário dos Pretos $e$, após longos discursos que contaram com presença liberal e republicana, marcharam pela rua do Carmo. Deram voltas, portanto, pela região do Pelourinho até chegarem à atual Praça do Riachuelo, na Cidade Baixa. O ministro da Guerra, Muritiba, que havia visto liberais e radicais se inflamarem na Corte, ordenou antes mesmo do 12 de março de 1870, quando chegou o $40^{\circ}$ Batalhão de Voluntários da Pátria a Salvador, que a recepção fosse curta, que as baixas fossem expedidas com celeridade e que fosse proporcionado transporte para o interior da província, "evitando a aglomeração dessa massa de soldados desocupados na capital" ${ }^{27}$. E prosseguia:

As armas com que marcha o batalhão devem ser recolhidos no Arsenal de Guerra dessa província, mandando Vossa Excelência dissolver o mesmo batalhão e expedir os necessários títulos de baixa às praças no menor espaço de tempo em detrimento dos males que podem causar à sociedade esses soldados armados e endurecidos pela campanha. ${ }^{28}$

No fundo, o problema era menos os soldados do que a influência exercida por liberais e radicais sobre eles. Dois dias após a entrada dos baianos em Salvador, a

${ }^{23}$ Dezesseis de Julho, 26/02/1870 e 3/03/1870.

${ }^{24}$ Dezesseis de Julho, 3/03/1870.

${ }^{25}$ Dezesseis de Julho, 3/03/1870.

26 Para uma detalhada descrição sobre o retorno dos veteranos às províncias, ver: SANTOS RODRIGUES, Marcelo. Guerra do Paraguai: os caminhos da memória entre comemoração e esquecimento. Tese de doutorado, Universidade de São Paulo, 2009.

${ }^{27}$ Arquivo Público do Estado da Bahia - Seção Colonial e Provincial. Ministério da Guerra, Maço 832. Muritiba para o presidente da província da Bahia, Barão de São Lourenço, 25/02/1870.

${ }^{28}$ Arquivo Público do Estado da Bahia - Seção Colonial e Provincial. 
presidência da província enviou despacho a Muritiba, alegando que a única forma de evitar o contágio de ideias desordeiras era o rápido pagamento dos soldos atrasados $^{29}$. Temia-se o pior em Salvador: alegavam as tropas que, no Rio, se havia prometido o pagamento dos soldos na Bahia. E quando chegaram na Bahia, disseram-lhes que era na Corte que o governo deveria ter saldado as pendências.

Havia alguma simetria entre a recepção dos veteranos em Salvador e na Corte: dúvidas quanto às promessas, discursos inflamados de liberais e de radicais, exigências de rápidas desmobilizações. Não foi diferente em São Paulo. O filho do general Osório contou que o $35^{\circ}$ Batalhão de Voluntários da Pátria chegou a Santos no começo de abril de 1870. As autoridades locais, nomeadas pelo governo conservador de Itaboraí, tinham disposto retratos de Caxias nas principais ruas da cidade. A tentativa de engrandecer o general conservador caiu rapidamente por terra quando desfilaram os veteranos. Eles, junto aos tantos civis que ali se aglomeravam, atiraram pedras nos retratos de Caxias, exigindo que se erguesse o de Osório. Em ato desesperado, as autoridades locais fizeram-no. E, ao ver a figura de Osório estendida diante do Banco Inglês, os veteranos saudaram "o general do povo" ${ }^{30}$. Talvez houvesse excesso nas palavras do filho de Osório, mas não destoaram do enredo geral sobre o regresso das tropas. Concluía então, dizendo a seu pai:

Não há dúvida, pois que o povo é seu. É preciso ser só do povo. Sim, o povo é a história que está viva [...]. É a única entidade poderosa que atravessa o tempo [...]. Com o povo tem-se tudo a ganhar; com o governo, nada. [...]. Gosto de ver a realeza obrigado a respeitar o povo, $e$ o dia em que este suplantar aquela os cidadãos irão ocupar um verdadeiro lugar, desaparecendo todos esses privilégios de reis e de dinastias $^{31}$.

Depois de Santos, os veteranos rumaram em trem até a cidade de São Paulo. Traziam-nos os vagões São Paulo Railway Company, que havia sido inaugurada pouco antes, em 1867. Desembarcaram na Estação da Luz e marcharam, em cortejo, até o Largo da Sé. Poucos dias depois, em maio de 1870, disparava o Correio Paulistano:

Quando encontrardes à margem de uma rua um velho soldado, acabrunhado ante o espectro da fome e da miséria, o que fareis, senhores? Voltar-lhes-eis a face? Deixá-lo, pois morrer, porque é sublime esse orgulho que não quer estender a mão à piedade? E, quando ao Voluntário a cuja porta baterdes, perguntardes: quem tu és? Responder-vos-á: chamei-me heroísmo, chamo-me miséria; chamei-me glória,

\footnotetext{
${ }^{29}$ Arquivo Nacional - Série Guerra, Ministério da Guerra. IG1-127. Barão de São Lourenço para Muritiba, Salvador, 14/03/1870.

${ }^{30}$ Instituto Histórico Geográfico Brasileiro - Lata 226, Pasta 70. Fernando Osório para Marquês de Herval, São Paulo, 14/05/1870.

${ }^{31}$ Instituto Histórico Geográfico Brasileiro - Lata 226, Pasta 70...
} 
chamo-me mendicidade; chamei-me vitória do patriotismo, chamo-me o vencido pela ingratidão ${ }^{32}$.

Era aquele novo exagero de um jornal que, pouco depois, assumiria a bandeira republicana? Muito provavelmente, para os conservadores. Ocorre que, exagero ou não, o retorno das tropas havia tomado as proporções de um conflito partidário que os conservadores queriam evitar. A tensão não era somente carioca, baiana ou paulista. Onde houvesse desfile de veteranos, haveria excitação política. Os casos de Minas Gerais, de Pernambuco, do Rio Grande do Sul e de Santa Catarina eram provas suficientes: a tensão do momento havia-se alastrado por todo o Império.

Em maio de 1870, começaram os preparativos para uma festa pública, inteiramente projetada pelos conservadores. O governo de Itaboraí compreendeu que era hora de organizar a memória cívica da Guerra do Paraguai, para não perder a querela do regresso. Fundar um momento ritualístico era de maior importância, tanto para evitar que as recordações sobre o retorno dos veteranos fossem poluídas por liberais ou por radicais, quanto para promover a unidade coletiva que parecia faltar no começo de 1870. Comemorar era anular ou suspender os conflitos; era escolher o que deveria ser lembrado e o que teria de ser esquecido ${ }^{33}$.

Entre projetos para erguer monumentos suntuosos, que não se concretizaram, o grande trunfo foi o Templo da Vitória. Visto que o tempo apertava, o monumento teria de ser feito em material provisório. Madeiras de cedro, maçaranduba ou pinho eram as opções mais baratas. O interior teria revestimento em papelão, e o exterior, em lona. A construção teria em torno de trinta metros de altura, pouco mais de noventa de largura e menos de dez metros de profundidade. Duas arquibancadas, uma ao Norte e outra ao Sul, seriam suficientes para abrigar os 8.000 convidados. O custo total do projeto, incluídos os gastos com o desfile, os banquetes, os ornamentos e as missas, era de 200:000\$000 réis, o que pareceu exorbitante, inclusive, a alguns deputados conservadores.

\footnotetext{
${ }^{32}$ Correio Paulistano, $11 / 05 / 1870$.

${ }^{33}$ OZOUF, Mona. L'École de la France: essais sur la Révolution, l'utopie et l'enseignement. Paris: Éditions Gallimard, 1984, p. 43; NORA, Pierre (org.). Les lieux de mémoire. La République, la nation, la France. Vol. III. Paris: Éditions Quatro Gallimard, 1997.
} 


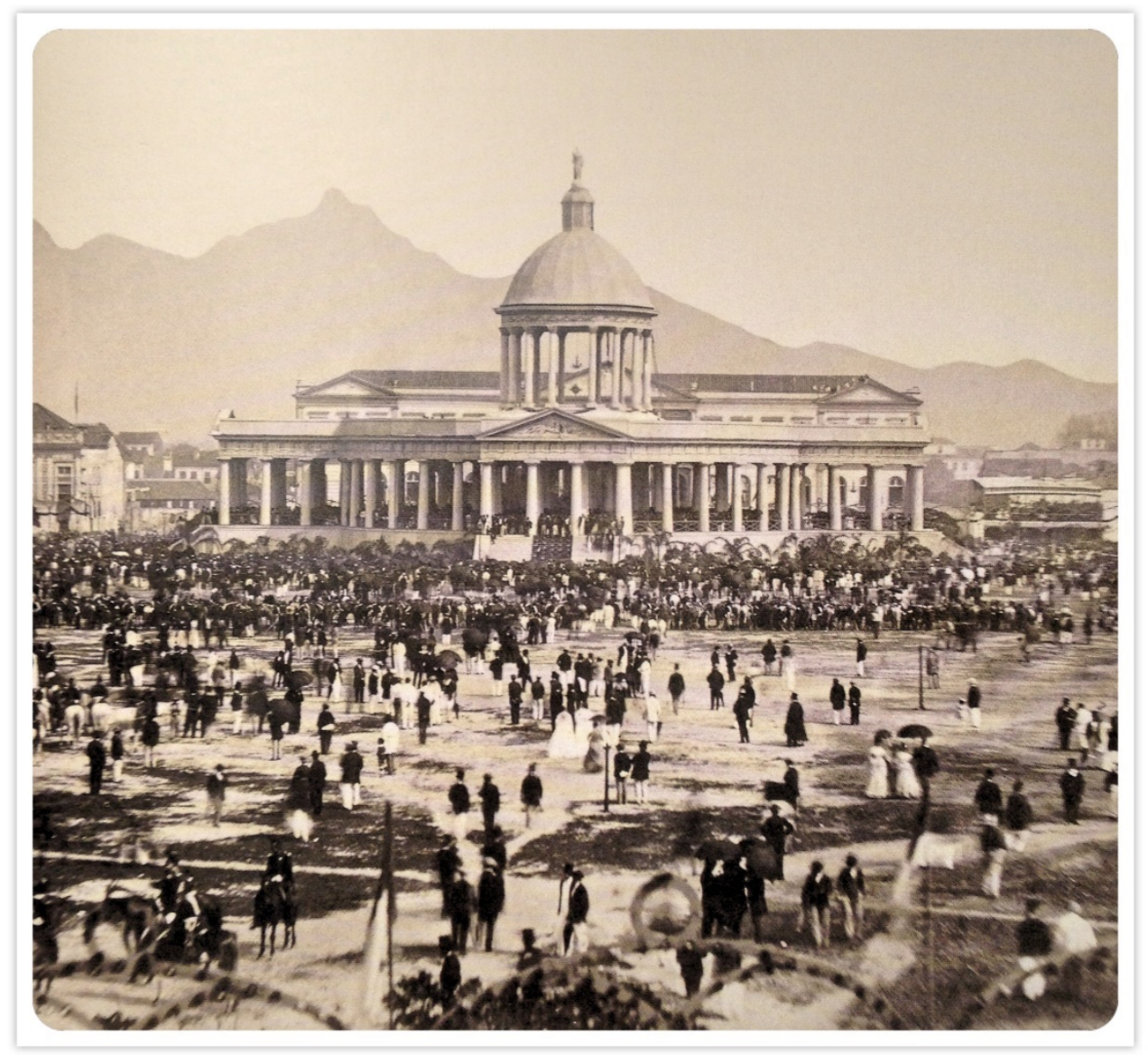

Figura 3: Templo da Vitória, construído em comemoração ao fim da Guerra do Paraguai. Fonte: Biblioteca Nacional - Fotógrafo: Marc Ferrez, Rio de Janeiro, 1870.

A título de comparação, o valor do templo correspondia a $1 / 4$ das despesas feitas com o Ministério dos Negócios Estrangeiros em $1871^{34}$. O Barão de Muritiba justificou o volume das despesas, afirmando que, dissolvido, o gasto não ultrapassaria 200 réis por contribuinte. Se entre os 10.000 .000 de brasileiros residentes no Império, continuava Muritiba, 1.000.000 fossem efetivamente tributáveis, conforme se suponha na Câmara, então o preço do Templo da Vitória seria de um quilo de arroz por contribuinte, ou 200 réis $^{35}$.

Após a justificativa de Muritiba, que estava presente na Câmara quando se discutiu o projeto, o deputado José de Alencar sobressaltou e, levantando-se da cadeira, disse que não era momento oportuno para gastar em comemorações patrióticas. $\mathrm{E}$ isso em que pese sua filiação ao partido conservador. Para ele, as celebrações na Corte, ainda em fevereiro de 1870, já haviam sido suficientes e, sobretudo, havia graves pendências quanto às pensões para filhos e esposas de praças falecidos em combate:

${ }^{34}$ CARREIRA, Liberato de Castro. História financeira e orçamentária do Império do Brasil. Tomo II. Rio de Janeiro: Fundação Casa de Rui Barbosa, 1980, p. 478.

${ }^{35}$ Anais da Câmara de Deputados, 19 de maio de 1870. Brasília: Câmara de Deputados. Disponível em: $<$ http://www2.camara.leg.br > . Acesso em: 9 de janeiro de 2016. 
"como é que quereis gastar 200:000\$000 réis quando ainda não enxugastes todas as lágrimas dos órfãos e das viúvas daqueles que pereceram na guerra?" ${ }^{36}$. Houve incômodo silêncio, que alguns pensaram ser decorrência da conhecida surdez de Muritiba. Mas não era somente isso. Entre a fumaça de tabaco que the era característica, o ministro da Guerra estufou o peito e, mantendo-se sentado, redarguiu:

O governo, de que o nobre deputado com tanta vantagem fez parte, jamais se tem olvidado de enxugar essas lágrimas, de proteger esses órfãos. [...]. As páginas do orçamento estão cheias de pensões concedidas às viúvas e aos órfãos daqueles que morreram defendendo a causa do Império: quem nesta luta se inutilizou ainda não deixou de encontrar socorro do Estado para prover a sua subsistência no resto de seus dias. O governo tem sempre submetido esses socorros à aprovação da Assembleia Geral, e não consta que a representação nacional tenha achado mesquinhas as pensões dadas pelo governo e por ela aprovadas ${ }^{37}$.

Sobre a política das promessas de campanha não se falava, a menos que a favor do governo. O notório aborrecimento de Muritiba devia-se ao tolhimento que o deputado conservador poderia engendrar quanto à aprovação do Templo da Vitória. Eram argumentos para a oposição, embora a Câmara fosse inteiramente conservadora.

Muito mais do que a reação de Muritiba, foi motivo de surpresa o programa oficial para a inauguração do Templo da Vitória, pelo menos para os que, naquela altura, ainda não suspeitavam da politização do regresso. Não haveria desfile de Voluntários da Pátria nem da Guarda Nacional, mas somente de oficiais e, eventualmente, de algumas praças de linha. A festa, no projeto do ministério da Guerra, deveria ser católica, e não militar. Primeiro, se cantaria um te-déum; em seguida, o desfile de oficiais sob os aplausos da família imperial e dos membros do gabinete; por último, a sessão dos discursos solenes. O Campo da Aclamação e o interior do templo seriam adornados com motivos e pinturas da companhia italiana de Nicolau Antonio Facchinetti. O traje oficial era de gala. $\mathrm{E}$, não menos importante, o 10 de julho, data prevista para a inauguração do templo, seria festa cívica repedida anualmente ${ }^{38}$.

Apesar das palavras de José de Alencar e do apoio a elas de algum outro deputado conservador, o projeto foi aprovado no dia 20 de maio de 1870. Foi um processo relâmpago, tendo-se em consideração que as discussões começaram apenas 7 dias antes da aprovação final. Foram 58 votos favoráveis a Muritiba, e 8 contra ${ }^{39}$. Pouco depois, o projeto trafegou pelo Senado, onde houve maior resistência: afinal, o

\footnotetext{
${ }^{36}$ Anais da Câmara de Deputados, 19 de maio de $1870 . .$.

${ }^{37}$ Anais da Câmara de Deputados, 19 de maio de $1870 .$.

38 Arquivo Geral da Cidade do Rio de Janeiro. 44.1.48. Programa e documentos anexos para a inauguração do Templo da Vitória.

${ }^{39}$ Anais da Câmara de Deputados, 20 de maio de 1870. Brasília: Câmara de Deputados. Disponível em: $<$ http://www2.camara.leg.br >. Acesso em: 9 de janeiro de 2016.
} 
Senado não tinha a unanimidade conservadora que caracterizou a Câmara após a constituição do gabinete de Itaboraí. No começo de junho de 1870, no entanto, o projeto tinha carta branca do poder legislativo, $e$ iniciaram-se as obras.

$\mathrm{O}$ de 10 de julho de 1870 foi um desastre, e isso a fotografia de Marc Ferrez não deixa transparecer (ver Figura 4). Dos 8.000 convites distribuídos para a inauguração do Templo da Vitória, em torno de 7.500 foram rejeitados. Ou seja, apenas 500 convidados compareceram. Eram visíveis os clarões das arquibancadas ${ }^{40}$. Os presentes ou eram membros do governo, ou do corpo diplomático estrangeiro: personagens, portanto, que por protocolo ou política não podiam faltar à festa. Havia também parentes de ministros e de deputados, e algum ou outro criado do paço. Não faltaram alguns poucos oficiais a cavalo, que tiveram de seguir às ordens de superiores $e$ ir à comemoração. Além deles, senhoras de longos vestidos brancos $e$ chapéus de sol acompanhavam maridos de cartola $e$ fraque. O que não se viu durante a festa, e aqui a imagem de Ferrez é reveladora, foi o povo. O povo de chinelos, de calças largas e de camisas surradas. Os liberais tampouco atenderam aos convites. Poucos dias antes da inauguração do Templo da Vitória, Nabuco de Araújo tinha deixado claro, no Senado, que a despesa com o templo era ilegal. Créditos extraordinários, consoante lei de 1850, somente poderiam ser concedidos em casos de calamidade pública. Não era o caso do 10 de julho de $1870^{41}$. Como outros da oposição, Nabuco de Araújo não foi à festa, que, naquela altura, parecia ser de Muritiba e dos conservadores.

Sem surpresa, mas com agravo, o governo teve de lidar com a imprensa de oposição, que fustigou até mais não poder o 10 de julho. Que remédio? Era notório o fiasco do Templo da Vitória, a ponto, inclusive, do Dezesseis de Julho, do Diário do Rio de Janeiro e do Jornal do Comércio, periódicos que apoiavam o governo, terem guardado silêncio completo sobre a questão. A Reforma falou sobre corrupção, improbidade, despotismo e patronato ${ }^{42}$. Em algum lugar, tinham razão. A festa não foi organizada para ser popular, e havia rumores sobre desvios de verba pública. Sobre eles tinha comentado o Conde d'Eu a seu pai, ainda em maio de 1870. Os créditos extraordinários aprovados ilegalmente não eram o único problema: havia-se contratado "um padeiro italiano que se casou com a filha de Itaborai", para ornar o Templo da Vitória. Falava de Facchinetti, não resta dúvida ${ }^{43}$.

\section{A voz das Forças Armadas}

A festa terminou antes do previsto. E, então, o termômetro político subiu alguns graus. A massa, que fora impedida de entrar no Campo da Aclamação durante a festa por ordens de Muritiba, rompeu as barreiras e tomou a praça. Eram pretos, mulatos e brancos, alguns carregando samburás e outros, pedras. Entraram também moleques descalços, que estavam nos arredores do Campo à procura da sorte, e foram

\footnotetext{
${ }^{40}$ A Reforma, 12/07/1870; Opinião Liberal, 12/07/70.

${ }^{41}$ Anais do Senado Federal, 7 de julho de 1870. Brasília: Senado Federal. Disponível em: http://www.senado.gov.br/publicacoes/anais. Acesso em: 9 de janeiro de 2016.

${ }^{42}$ A Reforma, 12/07/1870.

43 Arquivo Histórico do Museu Imperial - XLII-3 (17-19). Conde d'Eu para Duque de Nemours, Laranjeiras, 22/05/1870.
} 
misturar-se com as calças azuis dos fidalgos. Alguns destes, por vergonha ou medo, preferiam tirar as luvas e guardá-las nos bolsos ${ }^{44}$. Anunciava-se uma noite de "má índole brasileira", conforme previa A Reforma ainda nas vésperas do 10 de julho ${ }^{45}$.

A expressão havia sido escolhida a dedo. Tratava-se de um deboche à ritualística do Ministério de Justiça, que soia começar seus relatórios anuais afirmando que "a tranquilidade pública continu[ava] inalterável em todo o Império, graças à boa índole dos brasileiros". Deu-se o contrário naquela noite. Conta o Correio Paulistano que se haviam reunido 50.000 pessoas no Campo contra o governo ${ }^{46}$. Foi, provavelmente, um descomedimento de dois zeros. O episódio estava mais para 500 do que para 50.000 pessoas. Malgrado o exagero do Correio Paulistano, houve, sim, agitação popular. A massa foi especificamente buscar o ministro da Guerra, Muritiba. Eram antigos Voluntários da Pátria, militares de baixa patente e outros cidadãos comuns. Ao ver a turba, Muritiba e sua comitiva apressaram-se em deixar o Campo. De pouco adiantou, porque, às pressas, a multidão os seguiu. Quando se defrontaram, na altura do Teatro Lírico - ao Sul, portanto, do Campo da Aclamação -, o tropel abriu a boca. Gritaram uma e outra vez: "abaixo o ministro! Fora o Barão de Muritiba!" 47.

Estava claro que existia um canal de comunicação entre a oposição e a multidão. Liberais, especialmente, conseguiram passar a mensagem, embora não se tenha visto, ali no Teatro Lírico, liderança alguma do movimento. As recompensas do regresso auferidas pelo governo, naquela altura, eram dádivas sem contrapartidas. O caso mais grave foi o do capitão Galvão, que era um veterano da Guerra do Paraguai. Entre os oficiais presentes naquela confusão, um pequeno grupo tomou à frente da multidão e juntou-se a ela nos brados contra Muritiba. Foi uma decisão da hora, espontânea, e não premeditada. Ao perceber a aproximação de oficiais inferiores, Muritiba não duvidou. Deu voz de prisão, ordenando, para tanto, prontidão aos superiores das Forças Armadas. O capitão Galvão tornou-se espécie de bode expiatório do 10 de julho. No dia seguinte, Muritiba ordenou que Galvão fosse recolhido à Fortaleza da Lage. Ficaria preso e perderia o posto de capitão. Desesperado, Galvão escreveu diretamente ao Imperador, rogando justiça:

Não é uma graça que venho pedir a Vossa Majestade, e sim o reparo a uma violação de meus direitos de cidadão, como servidor do Estado, e a um ato despótico praticado pelo senhor ministro Muritiba [...], justamente reputado pelo Exército como seu maior perseguidor. Vários oficiais reunidos na noite dos festejos oficiais, afim de representaram a Vossa Majestade imperial contra um ministro que tanto tem acabrunhado aqueles que tudo sacrificaram pela causa da pátria durante uma longa campanha de cinco anos, achei de meu dever aderir a causa de meus companheiros e tomar parte na manifestação feita naquela noite. Firme na convicção de que o Exército não é o sustentáculo dos

${ }^{44}$ O Alabama, 23/07/1870.

${ }^{45}$ A Reforma, 10/07/1870.

${ }^{46}$ Correio Paulistano, 13/07/1870.

${ }^{47}$ A Reforma, 12/07/1870. 
governos opressores e impopulares, porque então seria $\mathrm{o}$ verdugo do povo, julguei-me com direito a essa manifestação pacífica como presenciou Vossa Majestade imperial, pois estava na persuasão de que aqueles que sacrificaram sua vida $e$ o futuro de suas famílias no campo de batalhas, tinham jus a queixar-se de um governo que por sua má administração tem excitado o clamor público em todo o Império: mas hoje acabo de convencer-me de que labutava em uma ilusão, e de que nós, militares, só temos direito de perder o braço, uma perna ou a cabeça, quando o país necessitar. [...]. Se fosse possível a Vossa Majestade ouvir todos os oficiais e soldados do Exército, convencer-se-ia de que são raros os que não hajam sido maltratados pelo atual ministro da Guerra, que tem causado a retirada de muitos oficiais distintos das fileiras do Exército ${ }^{48}$.

Dom Pedro, que certamente correu para os jornais de oposição após o fiasco do Templo da Vitória, provavelmente arregalou os olhos quando leu as ponderações de Galvão sobre o suposto caráter pacífico da manifestação. O caso era preocupante. Um oficial, ainda que inferior, tornava pública uma carta escrita ao Imperador por intermédio de A Reforma, jornal amplamente lido pelos tropas, inclusive, ainda durante a campanha do Paraguai. Se restava dúvida, elas dissiparam-se com o episódio de Galvão: havia contatos entre os liberais e o Exército.

A situação era grave, porque, mobilizado o Exército contra o governo, poderia haver queda de gabinete, o que geraria instabilidade política em momento de necessário ajuste econômico e, pior, faria o Exército crer, quiçá, em sua autonomia política. O melhor era fazer vista grossa. Dom Pedro II deixou o episódio para o esquecimento, malgrado reiterados artigos sobre o caso em A Reforma e na Opinião Liberal $^{49}$. Galvão faleceu em 1877 , após ter sofrido maus-tratos na prisão e ter conseguido alguns postos secundários em repartições administrativas do Exército ${ }^{50}$. Em julho de 1870, no entanto, a capital parecia um barril de pólvora. "Não nos esqueceremos do Templo do papelão", advertia-se em A Reforma ${ }^{51}$, enquanto a Opinião Liberal continuava açoitando o ministro da Guerra:

Muritiba só vê revoluções. Mandou espionar a cidade por quarenta oficiais, para ouvir o que se diz nos grupos de mais de três pessoas. Deu ordens para que se prenda os que falem contra a tranquilidade pública ${ }^{52}$.

Era a posição de Galvão, contudo, sintomática daquilo que pensava a integralidade das Forças Armadas? Certamente, não. O Estado-Maior Geral, tanto do

\footnotetext{
${ }^{48}$ A Reforma, 17/07/1870.

${ }^{49}$ A Reforma, 4/01/1871, 22/05/1873; Opinião Liberal, 23/07/1870, 18/09/1870.

${ }^{50}$ Arquivo Histórico do Exército - Almanaque do Exército de 1877.

${ }^{51}$ A Reforma, 12/07/1870.

${ }^{52}$ Opinião Liberal, 18/09/1870.
} 
Exército quanto da Marinha, não apresentava inclinação liberal, nem muito menos republicana (ver Tabelas 1 e 2). Contavam-se nos dedos aqueles que assumidamente eram ligados ao partido liberal: Osório (Marquês de Herval), José Antônio Correia da Câmara (Visconde de Pelotas), Henrique de Beaurepaire Rohan, no Exército; e Joaquim Raimundo de Lamare e Jesuíno Lamego Costa, na Marinha.

Havia também os que apresentavam tendência liberal, embora não estivessem diretamente ligados ao partido, como Vitorino José Carneiro Monteiro (Barão de São Borja). Do outro lado do espectro político, estavam os reconhecidamente conservadores: o Duque de Caxias e o Barão da Gávea, no Exército; o Visconde de Tamandaré e o Barão do Amazonas, na Marinha. A grande maioria do Estado-Maior Geral das Forças Armadas, no entanto, era da caserna, sem assumir ligação política qualquer: esses não questionariam os comandos superiores - portanto, do marechal do Exército e do almirante da Marinha -, que eram conservadores.

TABELA 1: INCLINAÇÃO LIBERAL NO EXÉRCITO EM 1870

\begin{tabular}{|c|c|c|c|c|}
\hline $\begin{array}{l}\text { Graduação } \\
\text { militar }\end{array}$ & Nome & Efetivo & $\begin{array}{c}\text { Veterano } \\
\text { da Guerra } \\
\text { do } \\
\text { Paraguai? }\end{array}$ & $\begin{array}{c}\text { Inclinação liberal em } \\
1870 ?\end{array}$ \\
\hline $\begin{array}{l}\text { Marechal do } \\
\text { Exército }\end{array}$ & Duque de Caxias & 1 & Sim & Nāo \\
\hline $\begin{array}{l}\text { Tenentes- } \\
\text { generais }\end{array}$ & $\begin{array}{l}\text { Barăo de Itapagipe; Joăo Frederico } \\
\text { Caldwell;: Marqués do Herval; } \\
\text { Visconde de Sanca Teresa }\end{array}$ & 4 & $\operatorname{Sim}(4)$ & $\begin{array}{c}\text { Não (3) } \\
\text { Sim: } 1 \text { (Marquês do Herval) }\end{array}$ \\
\hline $\begin{array}{l}\text { Marechais de } \\
\text { Campo }\end{array}$ & 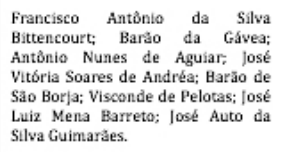 & 8 & $\operatorname{Sim}(8)$ & $\begin{array}{c}\text { Não: } 6 \\
\text { Sim: } 2 \text { (Barão de São Borja; } \\
\text { Visconde de Pelotas) }\end{array}$ \\
\hline Brigadeiros & 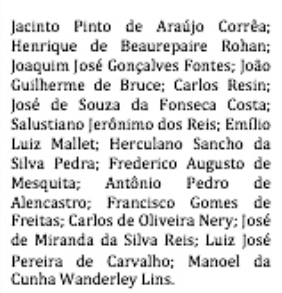 & 16 & $\operatorname{Sim}(16)$ & $\begin{array}{l}\text { Nāo: } 15 \\
\text { Sim: } 1 \text { (Henrique de } \\
\text { Beaurepaire Rohan) }\end{array}$ \\
\hline
\end{tabular}

Fontes: Arquivo Histórico do Exército - Fés do ofício respectivas a cada militar; Almanaque do Exército de 1870. LAGO, Laurênio. Os generais do Exército brasileiro de 1860 a 1889. Vol. III. Rio de Janeiro: Imprensa Nacional, 1942. PRETEXTATO MACIAL DA SILVA, Alfredo. Os generais do Exército brasileiro de 1822 a 1889. Vol. II. Rio de Janeiro: Biblioteca Militar, 1940.

Em rigor, as lideranças liberais tampouco eram grande risco para o governo. O que poderiam Osório ou Câmara contra o gabinete de Itaboraí? Pouco, acreditavam os conversadores, embora a eles não escapasse que Osório e Câmara eram figuras populares no Exército. Poderiam fazer oposição, é verdade, mas na política, e não na caserna. Com forte dose de razão, Itaboraí não vislumbrava a possibilidade de militares liberais erguerem regimentos contra o governo: a ruptura de hierarquia 
implicaria a exoneração dos rebeldes, e, melhor ainda, Caxias e Tamandaré opor-seiam rapidamente a qualquer movimento nessa direção. Osório e Câmara eram monarquistas, assim como Beaurepaire Rohan, Lamare e Lamego Costa; portanto, não passariam por cima do Poder Moderador, exercido por Pedro II. O que tampouco faria o Conde d'Eu, que era marechal do Exército honorário desde 1864: o príncipe consorte poderia influir na política, por intermédio do Conselho de Estado e pela óbvia proximidade com Pedro II, mas não levantaria o Exército, em que pese sua popularidade militar, contra um gabinete empossado pela Coroa. Os riscos seriam grandes demais.

TABELA 2: INCLINAÇÃO LIBERAL NA MARINHA EM 1870

\begin{tabular}{|c|c|c|c|c|}
\hline $\begin{array}{c}\text { Graduação } \\
\text { militar }\end{array}$ & Nome & Efetivo & $\begin{array}{l}\text { Veterano da } \\
\text { Guerra do } \\
\text { Paraguai? }\end{array}$ & $\begin{array}{l}\text { Inclinação } \\
\text { liberal em } \\
1870 ?\end{array}$ \\
\hline Almirante & Visconde de Tamandaré & 1 & Sim & Não \\
\hline $\begin{array}{l}\text { Vice-Almirante e } \\
\text { Vice-Almirante } \\
\text { Graduado }\end{array}$ & $\begin{array}{c}\text { Diogo Inácio Tavares; fosquim Raimundo de } \\
\text { Lamare; Barăo do Amazonas; Joào Marta } \\
\text { Wandenkolk }\end{array}$ & 4 & Sim (4) & $\begin{array}{l}\text { Não (3) } \\
\text { Sim: } 1 \text { (Joaquim } \\
\text { Raimundo de } \\
\text { Lamare) }\end{array}$ \\
\hline $\begin{array}{l}\text { Chefes de Esquadra } \\
\text { e Chefe de } \\
\text { Esquadra } \\
\text { Graduado }\end{array}$ & $\begin{array}{c}\text { Jesuino Lamego Costa; Elisiário Antônio dos } \\
\text { Suntos; Francisco Cordeiro Torres e Alvim; Barào } \\
\text { da Passagem; Josquim Manoel de Otiveira } \\
\text { Figueiredo }\end{array}$ & 5 & Sim (5) & $\begin{array}{c}\text { Não: } 4 \\
\text { Sim: } 1 \text { (Jesuíno } \\
\text { Lamego Costa) }\end{array}$ \\
\hline $\begin{array}{l}\text { Chefe de Divisão e } \\
\text { Chefe de Divisão } \\
\text { Graduado }\end{array}$ & $\begin{array}{l}\text { Felipe José Ferreira: Raphael Mendes de Moraes : } \\
\text { Vale; Francisco Pereira Pinto; Antonio Feliz } \\
\text { Corrèa de Mello; Fernando Lázaro de Lima; } \\
\text { Hermenegildo António de Barros; Vitónio José } \\
\text { Barbosa da Lomba: José Antônio de Faria: } \\
\text { Mamede Simóes da Silva; José Ferreira }\end{array}$ & 10 & $\operatorname{Sim}(10)$ & Não: 10 \\
\hline
\end{tabular}

Fontes: Arquivo da Marinha - Fés do ofício respectivas a cada militar; Almanaque da Marinha de 1870. BOITEUX, Lucas Alexandre. Ministros da Marinha. Notas biográficas (1865-1889). Rio de Janeiro: Imprensa Naval, 1959.

Para os conservadores, o problema das Forças Armadas estava nos oficiais inferiores, especialmente, do Exército: eram eles que entravam em contato com os praças, exercendo influência que poderia ser deletéria para a ordem hierárquica. Inclusive antes da Guerra do Paraguai, os oficiais inferiores haviam mostrado algum sinal de politização. Reclamavam reformas que iam além daquelas relativas à corporação. Eram favoráveis à abolição, às tarifas protecionistas, aos subsídios à indústria, à livre associação, à construção de estradas de ferro, a tornar as eleições diretas $^{53}$. Em sua grande maioria, eram jovens oriundos das camadas médias e

${ }^{53}$ SCHULZ, John. O exército na política. Origens da intervenção militar, 1850-1894. São Paulo: Editora EDUSP, 1994, p. 35-53. 
populares, cuja única experiência de guerra, a diferença do Estado-Maior Geral, foi a do Paraguai ${ }^{54}$.

Ao retornar dos campos de batalha, esses oficiais inferiores mostraram-se dispostos a fortalecer a corporação militar. As reformas de maior premência eram, em primeiro lugar, a dos soldos do Exército e, em segundo, a do recrutamento. Qual atrativo, se não para as camadas populares, poderia ter uma caserna cujos alferes ganhavam em torno de $432 \$ 000$ réis anuais? Era pouco menos do que ganhava um bom carpinteiro na Corte. Não por acaso, em 1871, oficiais inferiores como Floriano Peixoto, Feliciano Benjamin, Barreto Niemeyer, Jacques Ourique, Sena Madureira, Oliveira Guimarães e Severiano da Fonseca organizaram o Instituto Militar ${ }^{55}$. Embora a instituição se dissesse orientada para o melhoramento da corporação, houve temor quanto a sua provável politização, $e$ foi extinta por decisão do Conselho do Estado poucos meses depois de sua criação.

O caso é que a participação na Guerra do Paraguai conferiu aos oficiais inferiores um sentido de unidade. O sacrifício de guerra teria de redundar em melhorias na corporação. E quanto a isso, o Estado-Maior não se opôs. Pelo contrário, os apoiou. Faziam coro, portanto, ao pressionar o gabinete de Itaboraí por melhores soldos. Permaneceriam frustrados, no entanto, pelo menos até o gabinete do Visconde do Rio Branco, tendo em vista as dificuldades orçamentárias do Império após o conflito no Prata.

Outra questão, no entender do Estado-Maior, era quando os oficiais inferiores ultrapassavam os limites das reivindicações corporativas. Nesses casos, restava a punição. O Estado-Maior não secundaria um oficial inferior disposto a agitações políticas. O exemplo do capitão Galvão era prova suficiente. O Estado-Maior, em respeito à ordem constitucional e ao governo, não toleraria uma mobilização de praças por oficiais inferiores. Nem muito menos uma mobilização civil com participação de oficiais inferiores. Novamente, o exemplo de Galvão falava alto: nenhum oficial liberal do Estado-Maior veio ao socorro do capitão recluso.

Floriano Peixoto, principal liderança do Instituto Militar, havia entendido o recado. No que seria mais tarde uma estranha virada da história, Floriano, futuro presidente da República, escolheu o Conde d'Eu para ser presidente do Instituto. Era forma de garantir, por vias legais, a politização dos oficiais inferiores. O príncipe consorte terminou por rejeitar o convite, mas não por isso os oficiais inferiores permaneceriam silenciosos. Pelo contrário, à medida que ascenderam na hierarquia militar, buscaram tecer laços de identificação entre o Exército e aqueles que os republicanos chamavam de oprimidos. O que não quer dizer que o Exército fosse republicano em $1870 .^{56}$

A querela do regresso não teve vitoriosos. Os radicais não ganharam as Forças Armadas, longe disso. Naquela altura, a república não era vista como alternativa para

${ }^{54}$ DUDLEY, William. Institutional sources of officer discontent in the Brazilian Army, 1870-1889. The Hispanic American Historical Review, Durham, vol. 55, no. 1. Feb., 1975, p. 44-65.

Professionalization and politicization as motivational factors in the Brazilian army coup of $\overline{15 \text { November }}$ 1889. Journal of Latin American Studies, Cambridge, vol. 8, no. 1. May, 1976, p. 101-125.

${ }_{55}$ Arquivo Histórico Museu Imperial - Maço 160, doc. 7440. Carta de Floriano Peixoto para o Conde d'Eu, Rio de Janeiro, 24/09/1871.

${ }^{56}$ A esse respeito, ver LEMOS, Renato. "Benjamin Constant: the 'Truth' behind the Paraguayan War". In: KRAAY, Hendrik e WHIGHAM, Thomas (orgs.). I die with my country: perspectives on the Paraguayan War. Nebraska: University of Nebraska Press, 2005. 
alcançar as reformas na corporação. Não era sequer uma real hipótese para a caserna. As mudanças adviriam dentro da ordem monárquica, pensava-se então. Os radicais fracassaram também no que concerniu à adesão da população carioca contra a monarquia: ali, no Campo da Aclamação, a massa havia gritado contra o governo, e não contra o regime. Os liberais tampouco foram os vencedores da batalha do regresso. Em que pese o Conde d'Eu ou o boca a boca que varreu a Corte para tornar a inauguração do Templo da Vitória um fiasco, os liberais não conseguiram derrubar o gabinete de Itaboraí. E o Exército, em que pese os oficiais inferiores, não estava disposto a respaldar uma posição de força em benefício dos liberais. Os conservadores, enfim, não lograram neutralizar as Forças Armadas, que, após a guerra, adensaram suas pressões por reformas corporativas. Pior, eram donos de um governo impopular. O Templo da Vitória, prontamente desmontado, era a principal confirmação. E, em meio à disputa entre radicais, liberais e conservadores, regressavam ao Império os veteranos, que também passaram a buscar um lugar ao sol.

\section{$\operatorname{son} 2$}

\section{RESUMO}

O retorno dos veteranos ao Império deu origem a uma querela política que atravessou o ano de 1870. Para o governo conservador de Itaboraí, sujeitar as Forças Armadas era de maior importância, tendo em vista a influência que liberais reformistas buscavam exercer na caserna. Embora os conservadores não enxergassem grande risco nos oficiais liberais do Exército, não por isso deixaram que o reformismo, sobretudo por iniciativa dos civis, se alastrasse entre os militares. Quanto aos liberais radicais, estimava o gabinete que havia mais palavras inflamadas do que possibilidades de ação concreta. O que não quer dizer que os radicais tenham poupado esforços para republicanizar as tropas. $\mathrm{O}$ artigo analisa como se deu o embate pelo apoio das Forças Armadas quando do retorno dos veteranos da Guerra do Paraguai e em que medida o efeito desse embate foi realçar a autonomia da caserna.

Palavras Chave: Guerra do Paraguai; veteranos; politização; Forças Armadas; Império do Brasil.

\begin{abstract}
The veterans' return to the Brazilian Empire sparked a political controversy that marked the year of 1870. Fearing the liberal reformists' influence upon the military, it was fundamental for the conservative government of Itaboraí to ensure control of the Armed Forces. Even though the conservatives did not perceive the Army's liberal officers as a threat, they sought to prevent any influence that civilian reformists could exert on the Armed Forces. As to liberal radicals, the government understood that their power to cause trouble was limited. Nevertheless, this assessment should not dwarf the radicals' efforts to instil republicanism within the Armed Forces. The article analyses the political quarrel for the Armed Forces' support immediately after the return of the Paraguayan War veterans and intends to evaluate to what extent this controversy contributed to strengthen the military's autonomy.
\end{abstract}

Keywords: Paraguayan War; veterans; politicization; Armed Forces; Brazilian Empire.

Artigo recebido em 24 abr. 2017.

Aprovado em 14 jun. 2018. 